\title{
Collecting Small-Waste Electrical and Electronic Equipment in Poland-How Can Containers Help in Disposal of E-Waste by Individuals?
}

\author{
Piotr Nowakowski ${ }^{1, * \mathbb{C}}$, Sandra Kuśnierz ${ }^{2}$, Julia Płoszaj ${ }^{2}$ and Patrycja Sosna ${ }^{2}$ \\ 1 Department of Transport Systems, Traffic Engineering and Logistics, Faculty of Transport and Aviation \\ Engineering, Silesian University of Technology, ul. Krasińskiego 8, 40-019 Katowice, Poland \\ 2 LogistiCAD Student Research Group, Faculty of Transport and Aviation Engineering, \\ Silesian University of Technology, ul. Krasińskiego, 40-019 Katowice, Poland; \\ sandkus730@student.polsl.pl (S.K.); juliplo762@student.polsl.pl (J.P.); \\ patrsos942@student.polsl.pl (P.S.) \\ * Correspondence: Piotr.Nowakowski@polsl.pl
}

Citation: Nowakowski, P.; Kuśnierz, S.; Płoszaj, J.; Sosna, P. Collecting Small-Waste Electrical and Electronic Equipment in Poland-How Can Containers Help in Disposal of E-Waste by Individuals? Sustainability 2021, 13, 12422. https:// doi.org/10.3390/su132212422

Academic Editor: Md Tasbirul Islam

Received: 20 September 2021

Accepted: 7 November 2021

Published: 10 November 2021

Publisher's Note: MDPI stays neutral with regard to jurisdictional claims in published maps and institutional affiliations.

Copyright: (c) 2021 by the authors. Licensee MDPI, Basel, Switzerland. This article is an open access article distributed under the terms and conditions of the Creative Commons Attribution (CC BY) license (https:// creativecommons.org/licenses/by/ $4.0 /)$.

\begin{abstract}
The effectiveness of e-waste collection depends on organizational and social factors. Individuals should have easy access to collection points and be aware of proper methods of e-waste disposal. This article investigates the availability, usability, and occurring irregularities of the container collection of small-waste electrical and electronic equipment. The study explores the attitude and behavior of individuals when disposing of small-waste equipment in the South of Poland. The results show that ninety-five percent of supermarkets' managers responsible for waste management find a growing interest in the disposal of small e-waste by individuals. An increasing number of collection containers encourages residents to dispose of small-waste appliances. More than eighty-three percent of respondents are aware of proper methods of e-waste disposal. Additional information campaigns addressed to residents are required to prevent mixing electrical and electronic waste with other waste and to encourage the disposal of small e-waste. The intention to dispose of small e-waste was declared by only thirty-two percent of respondents. Containers with discarded easy breakable items, such as lamps, should be removed more frequently. The collection containers' noticeability is evaluated by individuals as of average difficulty. The containers in supermarkets have simple designs and labels indicating the category of waste for disposal. The containers installed in residential areas have attractive designs and advertising slogans. The individuals expect the containers should be available in more locations that are easily accessible from households. The results of this study should be helpful for local authorities, waste collection companies, and waste electrical and electronic organizations, to support design, location selection, and information campaigns for small e-waste container collections.
\end{abstract}

Keywords: waste electrical and electronic equipment; WEEE; small e-waste; social attitude; circular economy; collection methods; social awareness; containers for e-waste

\section{Introduction}

Waste electrical and electronic equipment (WEEE) or e-waste collections have been well-established for about fifteen years in the European Union (EU) and other countries such as Taiwan, Japan, and South Korea [1-3]. Learning from the experiences of WEEE management regulations, many other countries such as China and India introduced similar systems [4-6]. The collection rates of WEEE gradually increased [7,8]. A large variety of equipment requires various methods of waste collection [9]. In general, the collection can be conducted in stationary points such as municipal or local collection centers. Mobile collection methods, such as curbside collections [10] or on-demand waste collection [11], are also in the field of interest of collection companies. Large household appliances and 
information technologies equipment are categorized as e-waste with the highest collection rate [7]. This also applies to the countries where the collection equipment is collected by informal waste pickers [12]. However, it is more difficult to achieve a high collection rate for small household appliances and other small items belonging to other categories [13]. Small e-waste equipment includes small computer peripherals, mobile phones, tools, toys, kitchen and bathroom appliances, etc. The reason is that the behavioral patterns of individuals differ for various categories of WEEE [14,15]. When equipment is small, it encourages the residents to store or dispose of such equipment in an improper way [16,17]. It tends to happen especially when e-waste is mixed with other fractions such as plastics, metals, or even with general waste [18]. Comparing the collection rate of large household appliances and IT equipment with other categories of small dimensions e-waste in the EU in 2018, there is a difference indicating the necessity for improving collection effectiveness (Figure 1) [7].

Toys, leisure and sports equipment

Electrical and electronic tools

Small household appliances

Large household appliances

IT and telecommunications equipment
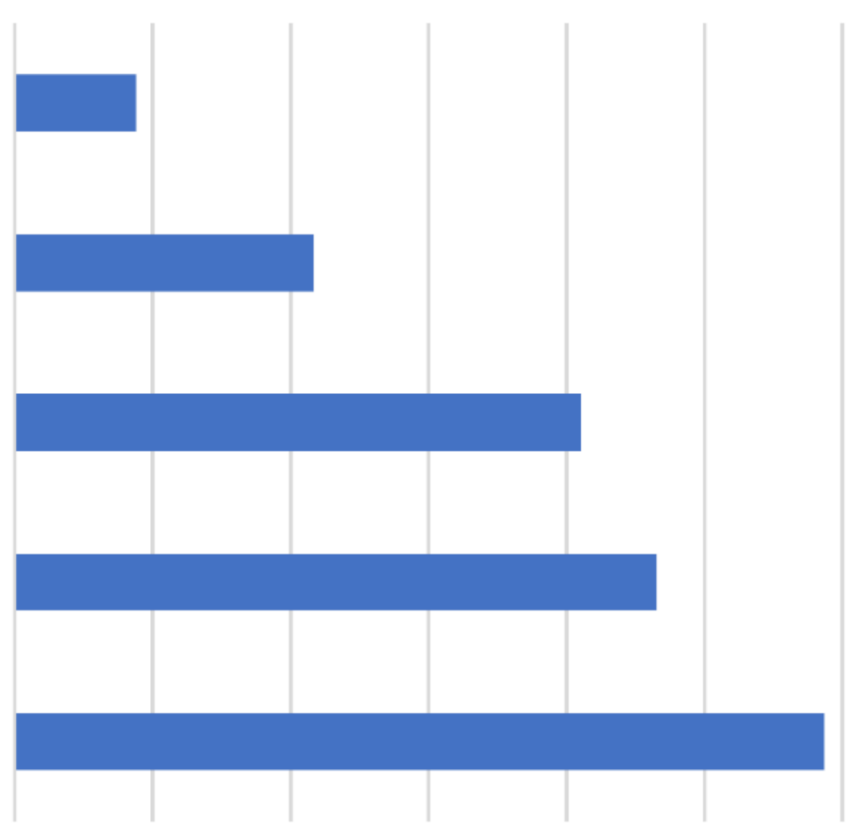

$0 \%$

$10 \%$

$20 \%$

$30 \%$

$40 \%$

$50 \%$

$60 \%$

$70 \%$

Figure 1. Proportion of waste electrical and electronic equipment collected in relation to new equipment placed on market in the EU in 2018 (source: Eurostat).

The EU WEEE Directive [2] created a framework for the efficient management of ewaste. The requirements take into consideration efficient collection methods, transportation, and treatment of end-of-life electrical and electronic equipment. The first principle is to prevent e-waste from being disposed of along with municipal waste. Another activity is to ensure easier collection of waste equipment. The possibility to dispose of WEEE has increased. E-waste can be disposed of in supermarkets, local and municipal collection centers, equipment repair shops, and mobile collections (curbside or on-demand). An additional opportunity is disposal points available during various events, such as charity or environmental theme events. Disassembly and treatment of e-waste equipment must not result in the contamination of the natural environment by hazardous substances contained in the waste equipment, and further, enable recycling of metals and plastics.

The regulations regarding e-waste in Poland comply with the EU WEEE Directive [19]. The required level of 65 percent collection rate of the equipment placed on the market is supposed to be achieved in 2021. The minimal level for the collection of WEEE is 60 percent of the equipment placed on the market for categories other than lighting equipment. For lighting equipment, 65 percent collection of the mass of this category equipment had to be 
achieved in 2020 [20]. In 2017, the mass of the electrical and electronic equipment placed on the market was 607,000 tons, and 246,000 tons of e-waste were collected. The collection rate compared to the mass of the equipment placed on the market was 40.5 percent. For the category of small household appliances, the collection rate was 37.7 percent; for electrical tools, 33 percent; and for toys, leisure, and sports equipment, only 31 percent [21].

The material content of the components used in electrical and electronic equipment depends on the category of e-waste. The majority of equipment used in kitchens and bathrooms includes plastics and common metals such as steel, aluminum, and copper [22]. Other equipment, i.e., toys, and information technology equipment (minor computer items or mobile phones), include more materials, and some of the materials are valuable, such as silver, gold, or rare-earth elements [23]. Some of the components are hazardous, such as condensers, printed circuit boards, or batteries [24]. It is important to prevent the environment from contamination by proper collection of WEEE from households. This task requires numerous activities. A collection company should provide suitable containers or collection boxes. These should be placed in areas frequently visited by residents. Other methods to ensure efficient waste collection are information and education campaigns for individuals [24-26]. The subject of the campaigns should highlight environmental issues. As a result, an individual should try to find an appropriate container for the disposal of small WEEE or even introduce economic incentives based on the electronic bonus card system [27].

The research considering the behavioral intentions of individuals and the attitude towards disposal of e-waste was the subject of studies in the EU. The results show various approaches towards recycling behavior of the e-waste among the residents of Romania and Italy [28]. The evaluation of the e-waste management system in France indicated a lack of involvement of local authorities and consumers, and a low recycling rate at the local level [29]. In Lithuania, the survey results highlight that a small amount of WEEE was discarded together with municipal waste. Residents expected more information about WEEE disposal options and more collection points [30]. A study in Portugal identified the sociodemographic factors that influence consumption and recycling behaviors on a case study of tablets and smartphones [31]. Other irregularities in the disposal of small e-waste are present in a case study from Ireland. It shows a tendency to store small e-waste among households [32]. The findings for a case study in Japan show that intentions to recycle e-waste are affected by environmental concerns and perceived benefits from engaging in this behavior [33]. In developing countries, socio-economic issues were identified as critical to be resolved in India because individuals are not aware of disposal methods of e-waste [34]. A case study in China shows the expectation of the government policies that promote WEEE recycling [35].

Our study evaluates the usage of containers for the collection of small household electrical and electronic appliances. It appears that waste collection companies cooperate with local authorities, managers of residential areas, supermarkets, and shopping malls to provide the residents with suitable methods for the disposal of small e-waste. One of the goals of this research is to investigate the effectiveness and experiences of the ewaste container collection from a managerial point of view. A semi-structured survey was prepared for the managers responsible for waste collections in supermarkets, shopping malls, and residential areas. An evaluation of the effectiveness of container collections by managers and of potential irregularities with small e-waste disposal is a starting point to explore attitude towards disposal of small e-waste, behavioral patterns of individuals, and the evaluation of the availability and noticeability of containers for e-waste. This part of our study uses an online survey. The third part of this study is a field study. It focuses on the evaluation of the containers' noticeability by individuals and, further, on the design of the containers. The article's goal is also to find some irregularities within the e-waste collection process. The results illustrated in this research can be beneficial for local administration and communities, waste collection companies, and for the producers of the containers. 
The recommendations will help to work out more effective advertising and information campaigns for individuals.

\section{Materials and Methods}

Two surveys and a field study were employed to investigate the effectiveness of e-waste containers' collection method. The first survey was addressed to managers of the supermarkets, shopping malls, or other employees responsible for e-waste management. We used a semi-structured survey to collect data. Another part of our research was an online survey for individuals in Poland. The goal was to identify awareness of individuals regarding e-waste management and behavior intentions concerning small e-waste. The final part of the investigation was a field study that assumed visiting containers' locations and explored their contents-if possible-in supermarkets, shopping centers, and residential areas.

The container collection of small WEEE has been evaluated in four urban municipalities of the Silesian region in the South of Poland. The research includes municipalities of Wodzisław Ślaski with a population of 48 thousand, Sosnowiec-198 thousand, Rybnik137 thousand, and Racibórz-55 thousand. In each city or town, the collection of small e-waste is provided in containers in municipal collection centers, supermarkets, shopping malls, residential areas, or seasonal placement of the collection points. Since 2015, new initiatives have been taking place to set up more containers in frequently visited places by residents. New projects for the placement of the collection containers for small e-waste started in Rybnik and Sosnowiec in 2020 and 2021. Figure 2 shows a map of the area with the location of small e-waste collection points.
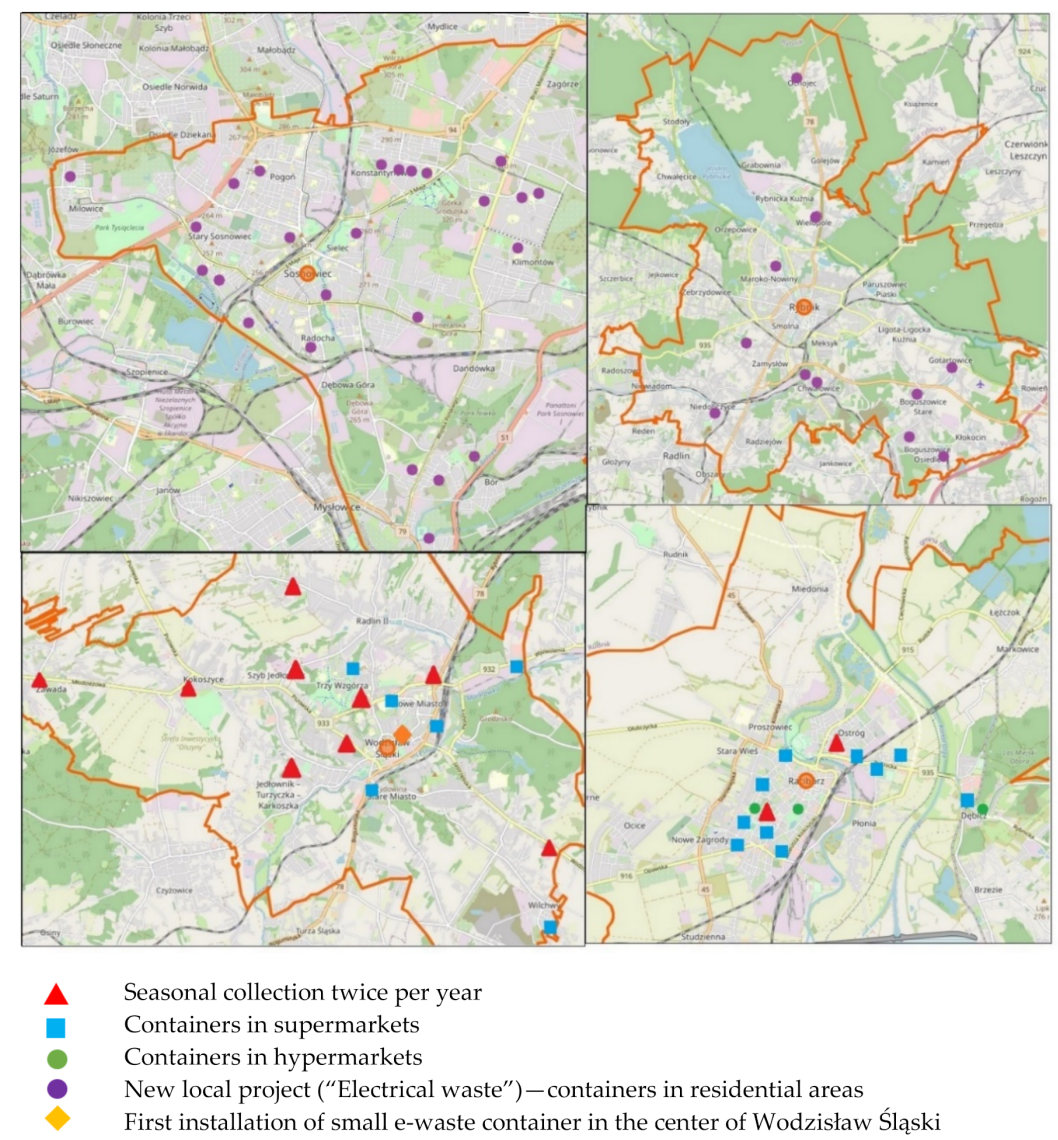

Figure 2. Map of four urban municipalities included in this study with location of containers for small e-waste collection in the Silesian region in Poland (source of maps: https:/ /www.openstreetmap.org accessed on 2 September 2021). 
Each community or municipality in Poland was required to provide a collection point of e-waste in the local waste collection center to comply with the WEEE Directive. Another step in improving the collection rate was the installation of sets of containers collecting e-waste in shopping malls and supermarkets. The final step towards the facilitation of the collection of e-waste for individuals was the placement of e-waste containers in convenient locations in residential areas (Figure 3). Another possibility for the collection is to arrange a seasonal collection of WEEE. It can happen every two, three, or six months in a specially selected place.

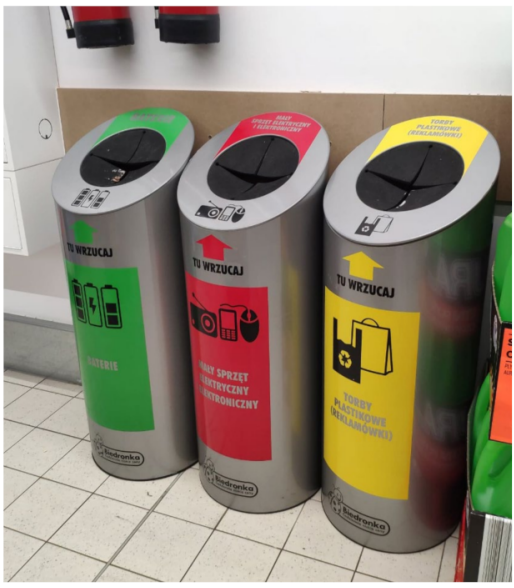

(a)

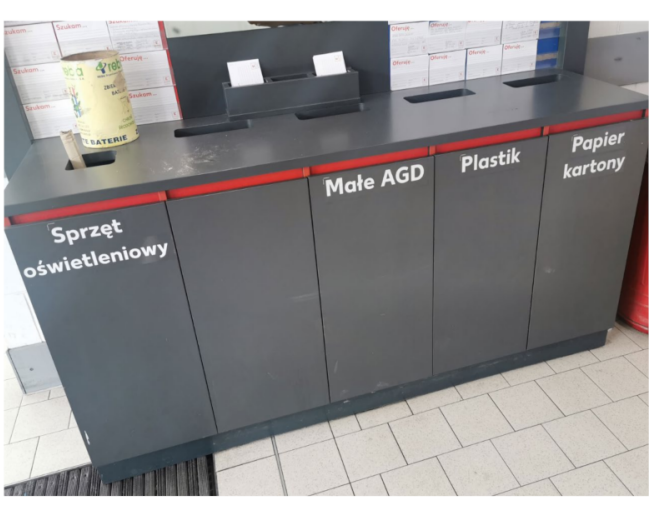

(b)

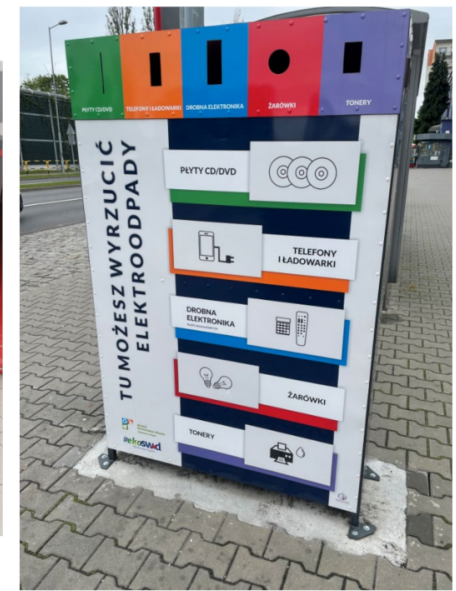

(c)

Figure 3. Examples of various types of containers for the collection of small e-waste in: (a) a supermarket (in the middle of a row); (b) a hypermarket (in the middle of a row); and (c) a residential area.

This study investigates and evaluates the methods for the collection of small WEEE. The main tasks, methods, and goals are shown in Figure 4.

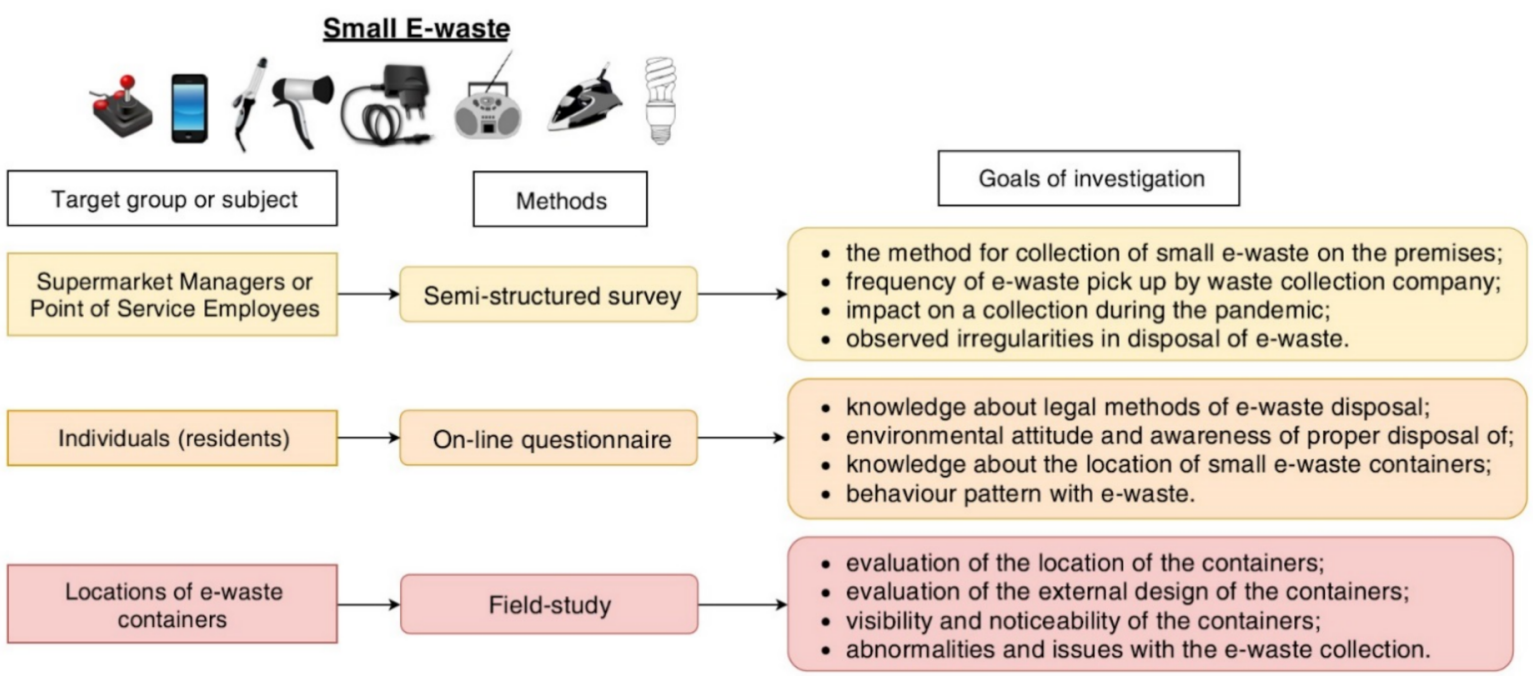

Figure 4. Research tasks, methods, and goals for investigation in this study.

The first survey focused on methods of collection in all locations eligible for placement of the containers. A semi-structured survey was distributed to managers of supermarkets and persons responsible for waste management in a municipal council and 25 responses were collected. The authors of this study visited the locations of the containers. In each place, a manager might have been asked to participate in the survey. There were some limitations due to pandemic restrictions. Therefore, it was difficult to interview each manager 
or employee responsible for waste management. There were five subjects surveyed with a choice to comment. These included the following questions:

- What is the method for the collection of small WEEE in a supermarket, shopping mall, or local area you are responsible for?

- How frequently does a collection company empty the containers?

- How often do the customers use the containers?

- Was there any impact on small e-waste collection due to pandemics?

- What are the issues with the containers or collected waste?

The next part of the research was an online survey sent via social networks to individuals in the Silesian region. Two hundred and fifty-one responses were collected. The purpose of the questionnaire focused on behavioral patterns and accessing information about knowledge and WEEE collection requirements. The details of respondents are shown in Table 1.

Table 1. Social information for the surveyed individuals.

\begin{tabular}{cc}
\hline Basic Information & Proportion of Total (\%) \\
\hline Age & \\
\hline$<18$ & $3.6 \%$ \\
$18-26$ & $49.6 \%$ \\
$27-35$ & $19.2 \%$ \\
$36-50$ & $20 \%$ \\
$>50$ & $7.6 \%$ \\
\hline Gender & \\
\hline Male & $42.8 \%$ \\
Female & $57.2 \%$ \\
\hline Size of municipality & \\
\hline$<5000$ & $22.4 \%$ \\
$5000-50,000$ & $25.2 \%$ \\
$50,000-200,000$ & $29.6 \%$ \\
$>200,000$ & $22.8 \%$ \\
\hline
\end{tabular}

The survey also included questions concerning container location awareness, compliance of residents with WEEE regulations, and attitude towards small e-waste collections. A part of the survey focused on the source of information about WEEE collections and the individual's noticeability of the containers.

The last part of the online survey investigated an intention to dispose of small e-waste and the frequency of disposal. The respondents were also asked to propose some ideas to improve both: the collection and knowledge of potential hazards on the natural environment.

The field study's purpose was to personally visit container locations in four urban municipalities in the Silesian region. Each location and container was evaluated, including the contents inside. The noticeability of the containers by passing individuals, labels, and signs printed on the collection containers was also analyzed.

\section{Results}

The results section has been divided into three subsections. Section 3.1 includes results of the semi-structured survey for the managers and employees responsible for waste management. A summary of the managers' comments was also presented in this section. It highlights some irregularities with the collections. Section 3.2 is the presentation of the online survey of individuals. The data collected from the questionnaire allows for investigating the attitude of residents towards disposal and recycling of e-waste, behavior, and intentions for discarding of small WEEE. Section 3.3 shows the results of the field study and illustration of the main issues encountered in containers' collection. 


\subsection{Results for the Semi-Structered Survey for the Managers}

The first part of this study's results indicates that ninety-five percent of managers find the customers dispose of small e-waste items on the premises of the supermarket or shopping mall. For the collection of small e-waste, special containers were placed in the communication arteries in a supermarket or shopping mall. In some cases, a vehicle on certain dates is parked outside to collect waste items. The waste collection company usually unloads the container once per month or after the container is full. The agreement between the supermarkets or shopping malls and waste collection companies allows one to schedule collection of e-waste with a possibility to call for the collection on-demand. The COVID-19 pandemic had little impact on the collection of small e-waste. The disruptions were only at the beginning of the pandemic, and only 38 percent of investigated managers indicated some influence on the collection. Additional responses to the survey included some important observations-the customers tend to dispose of small e-waste more frequently than they used to a few years ago. However, the amount of waste items inside is not significant compared with the number of customers in a supermarket or a shopping mall. The content of the containers includes other types of waste, and it is problematic. WEEE collection companies complain that the containers are solely for e-waste. General waste, plastics, paper, or other waste is the contamination of e-waste. It disturbs the recycling of WEEE in a treatment facility. The input material must be separated from all impurities before entering the e-waste equipment disassembly line, and therefore cleaning produces additional costs.

\subsection{Results for the Survey for Individuals}

The great majority of respondents-87 percent-are aware WEEE must be collected separately. Only a small fraction of respondents indicated disposal of this category with municipal waste as the right option. Another question was to distinguish two groups of respondents-a group that is aware of where the small e-waste container is located and another group of respondents that is unaware. Out of 251 respondents, 161 (61 percent of the total) answered they noticed a container-in a supermarket, residential area, hypermarket, or shopping mall, in a school, city, or village council (Figure 5).

Do you know if there is an e-waste container in the vicinity of your place of residence?

I do not know if there is a container for small e-waste in my neighbourhood

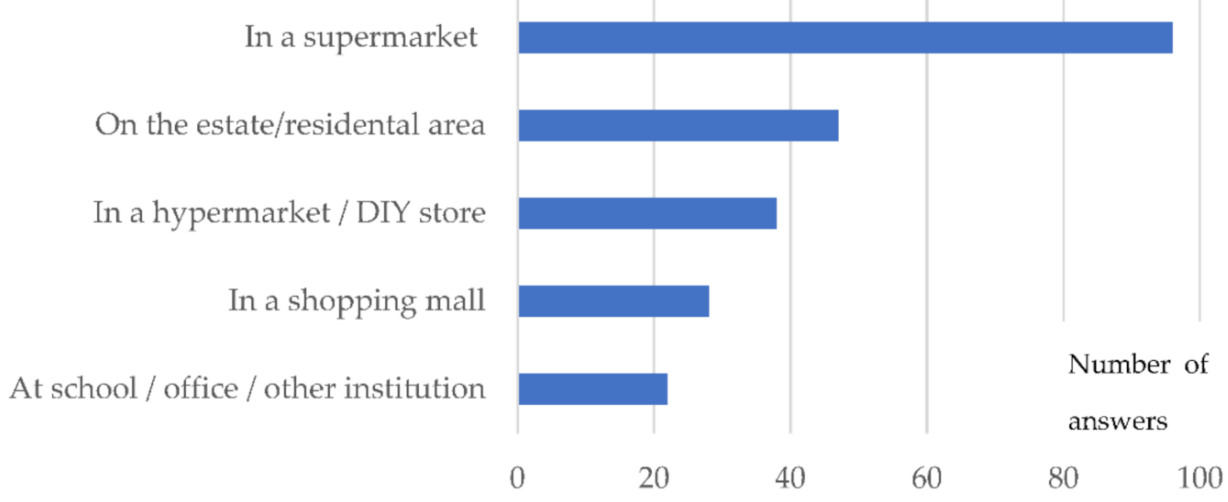

Figure 5. Knowledge of the residents about the location of small e-waste collection containers.

The next question explored the source of information about the location of the e-waste collection container. It showed the great majority of respondents indicated self-observation or third persons' advice (Figure 6). It showed that containers are easily noticeable and that there is a lack of broader information campaigns. Only about 9 percent indicated mass 
media, social channels, websites of the City Council, or waste collection companies as a source of information. The lowest number of respondents (4.3) percent were informed on educational courses or at schools.

\section{What is the information source on the location of small e-waste containers or collection points?}

\section{My own observations}

From third parties, friends, relatives

The mass media (internet, radio, TV)

A website of the City Concil or the waste collection company

School, from a course or from other educational activities

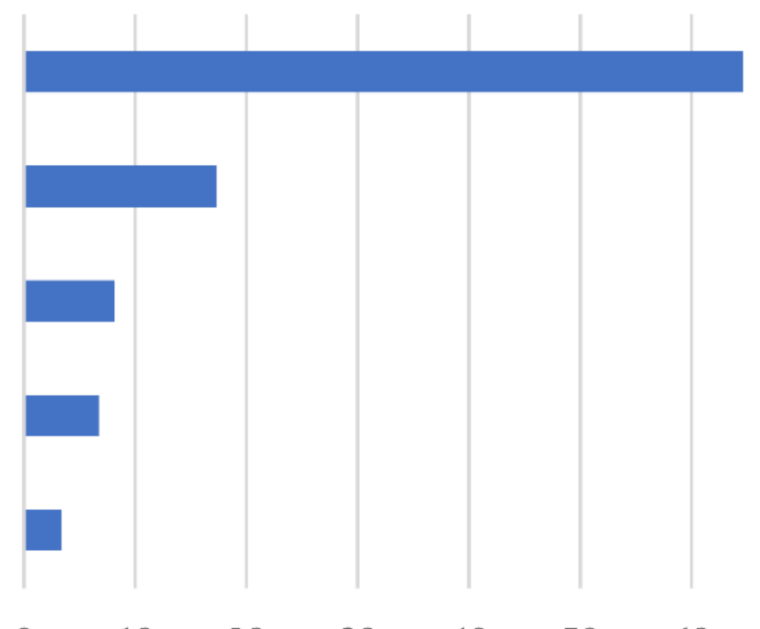

$0 \quad 10$

40

Figure 6. Identification of the information source of a resident regarding small e-waste collection points.

Considering evaluation of proper signs, labeling of containers, and design to inform passers-by, 40 percent of respondents find it as very easy or easy to notice such container and over 32 percent of residents find it to be of average difficulty (Figure 7).

\section{Assessment by an individual the visibility of small e-waste container (5 - best visibility, 1 - worst visibility)}

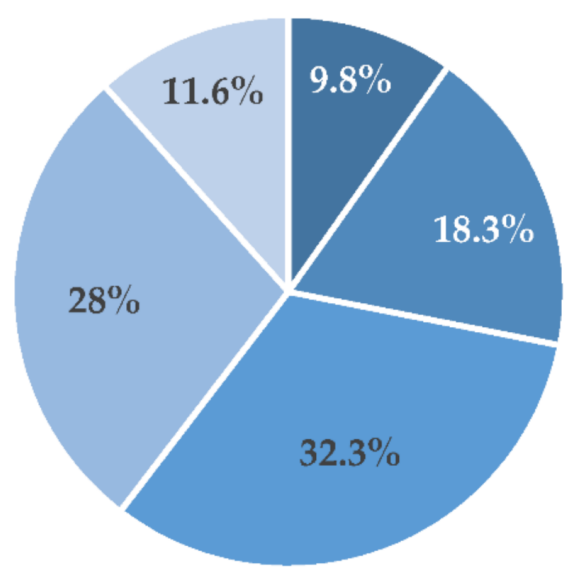

Figure 7. The assessment of the visibility of the small e-waste container by individuals.

An intention of disposal of small WEEE in the nearest future declared only 40 percent of respondents. An intention of disposal of small WEEE in the nearest future declared only 40 percent of respondents. Larger proportion of individuals answering "Probably not" or "No" may indicate a potential stockpiling of waste items in a household or other improper methods for disposal (Figure 8). 
Are you going to dispose of small e-waste in the near future?

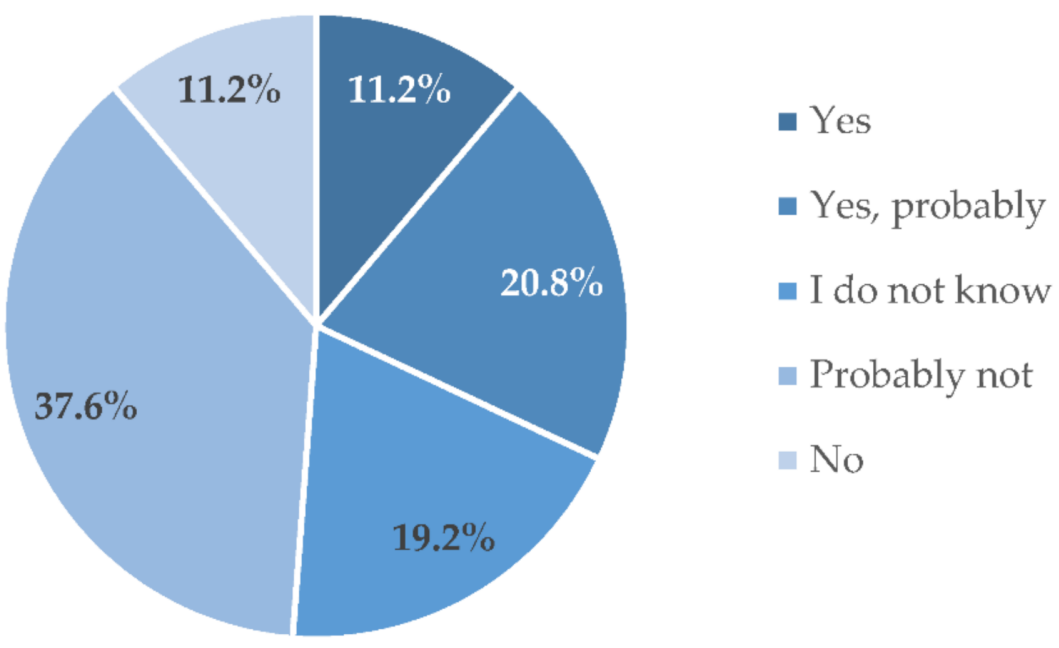

Figure 8. An intention for disposal of small e-waste by respondents.

The answers collected for the next questions can imply an intention of stockpiling waste items by residents because almost half of the respondents answered they dispose of small e-waste less than once per year (Figure 9). Twenty-two percent of respondents declared they discard of small e-waste once per year. It is unlikely that none of the items belonging to small equipment will break or become obsolete in the course of a year.

How often do you dispose of small E-waste?

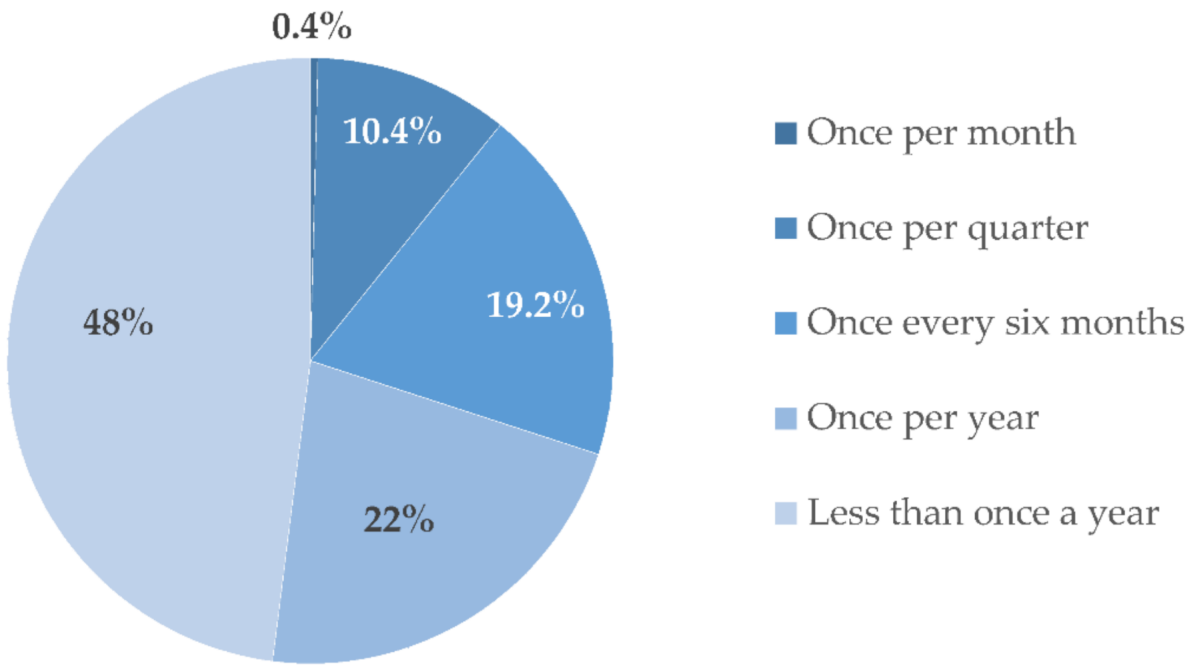

Figure 9. Frequency of disposal of small e-waste by respondents.

The last section of the survey explored the consciousness of individuals regarding the environment and the possible recycling of the collected e-waste (Figure 10). A great majority of respondents are aware of the high negative impact on the natural environment. Over 80 percent of individuals indicated a very high or high impact of e-waste on the environment. This is a result of broad campaigns presented frequently in mainstream media, social networks, websites, and other sources of information about hazardous properties of WEEE. 


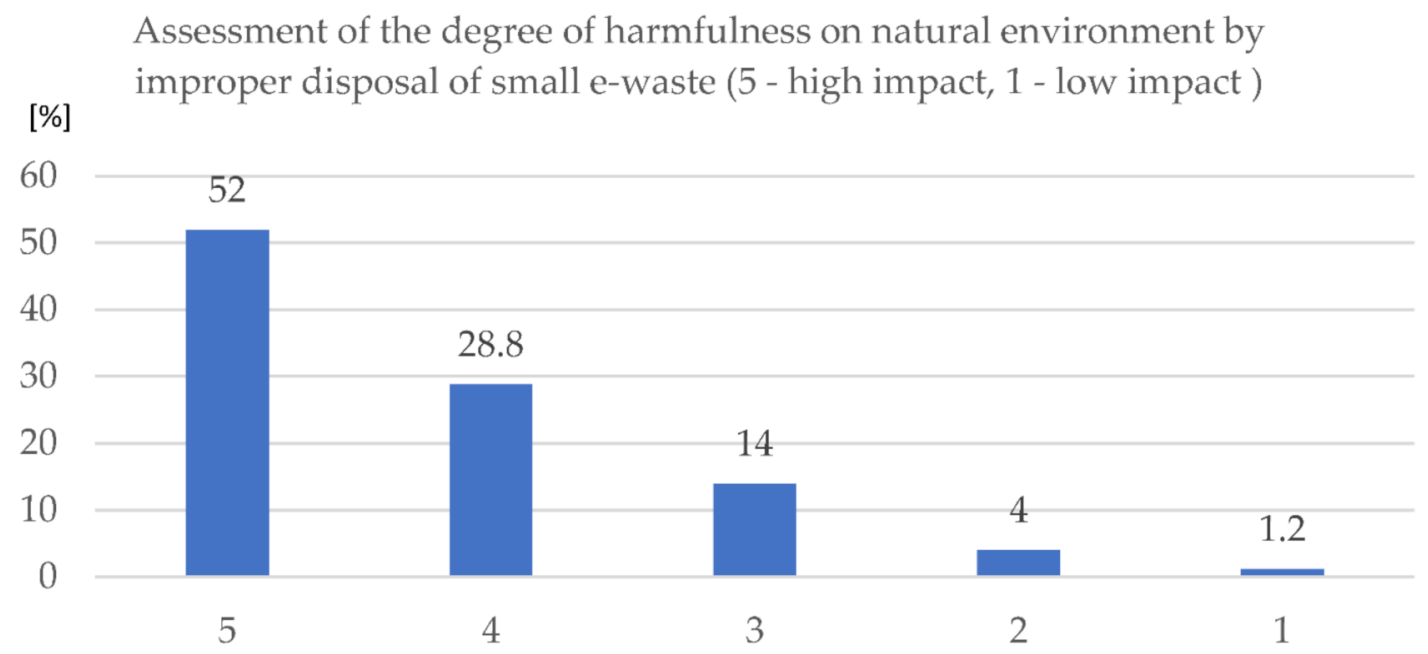

Figure 10. Assessment of the impact of e-waste on the environment by individuals.

The knowledge about the recycling potential of e-waste is relatively low. The results show that about half of the respondents are unaware that materials used in components of e-waste are recyclable. However, almost 42 percent of individuals taking part in the survey indicated that the materials used to build the electrical and electronic equipment are recyclable, compared to less than 9 percent who think the opposite (Figure 11).

\section{Are the raw materials used to build that equipment recyclable?}

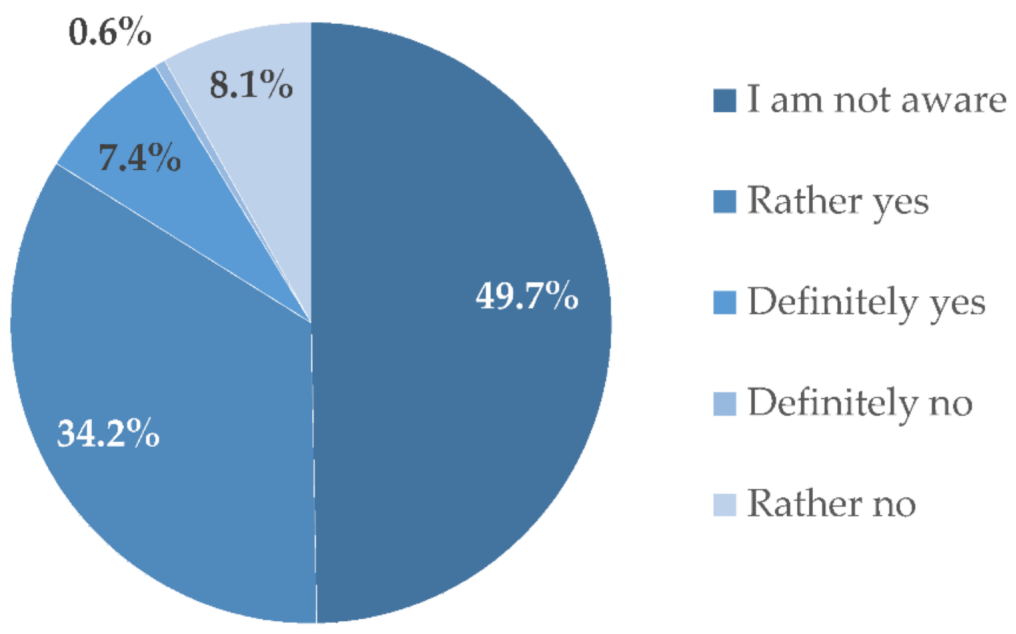

Figure 11. Awareness of recyclability of the materials in waste equipment by individuals.

\subsection{Results for the Field Study}

The third part of this research was the field study. The intention required visiting each location where a small e-waste container was placed, evaluating its noticeability, and checking what kind of waste is inside the container (if possible). The results show that a great majority of containers for small e-waste are placed in convenient location, i.e., -in shopping malls and supermarkets, accessible by individuals. The design and labels on the containers indicate what kind of equipment should be disposed of. In shopping malls, supermarkets, and hypermarkets, the containers for small e-waste are usually assembled with other containers for separated waste. The sets include separate containers for e-waste, bulbs and LED sources, compact or linear fluorescent lamps, and batteries. Additional waste collection containers are for paper, glass, and plastics (Figure 12). 


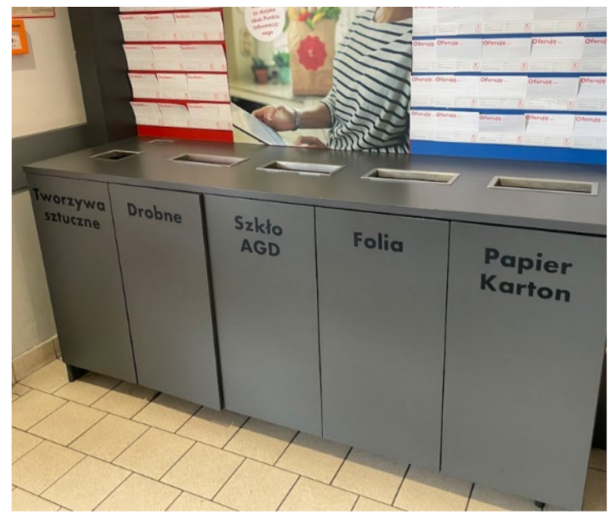

(a)

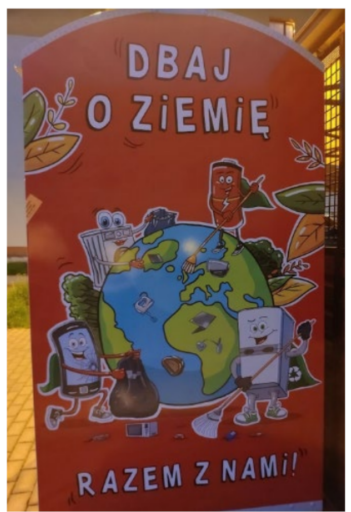

(b)

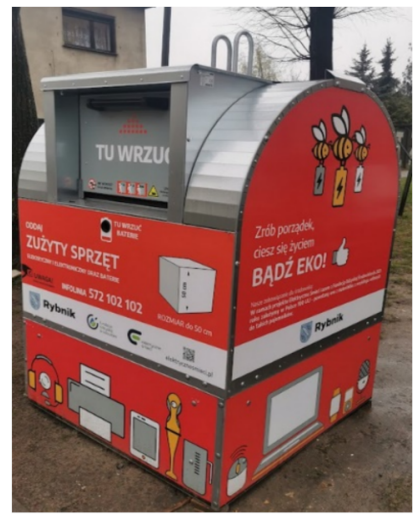

(c)

Figure 12. Design and labeling of small e-waste collection containers: (a) simple description of type of waste, (b) advertising slogan titled-“protect Earth", and (c) advertising slogan titled—“Be Eco" (slogans translated from Polish).

In the majority of places, the containers are located in easily accessible places and are visible and noticeable by passing by customers. The recently placed containers, in Rybnik and Sosnowiec, set up in residential areas include basic information about a category of waste for disposal. These also include advertising slogans to attract attention to a distinctive feature or purpose of the collection (Figure 12b,c). Such advertising slogans are missing in containers placed in shopping malls and supermarkets (Figure 12a).

Figure 13 shows major irregularities encountered in containers' collections of small ewaste. Two issues occurred most frequently: mixing various categories of waste (Figure 13a,b), especially with packaging materials (plastic bags and cardboard) and disposal of fluorescent lamps. They are fragile and can be easily broken with subsequent contamination of mercury. Figure 13c shows improperly stored cathode ray tubes and printers. Both types of equipment include hazardous substances easily released into the environment. In this case, the size of the waste equipment exceeds the dimensions of the input hole of the container.

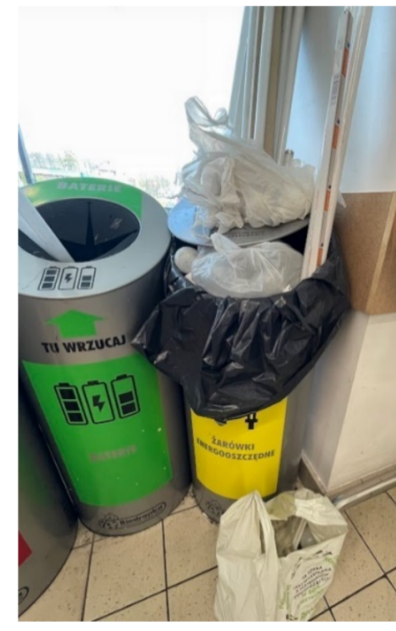

(a)

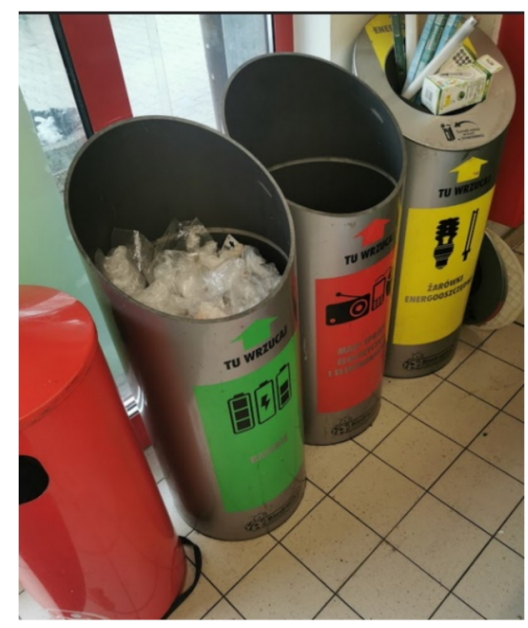

(b)

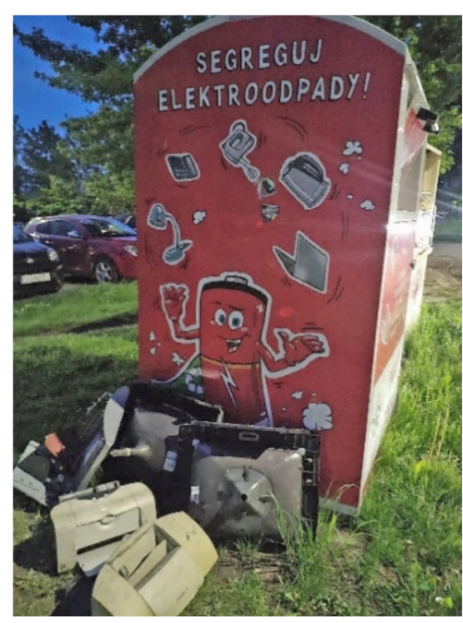

(c)

Figure 13. Samples of irregularities and issues with containers' collection of small e-waste: (a) protruded fluorescent lamps; (b) plastics mixed with other fractions; and (c) cathode ray tubes and printers put outside container.

Figure 13 shows major irregularities encountered in containers' collections of small e-waste. Two issues occurred the most frequently-mixing various categories of waste (Figure 13a,b), especially with packaging materials (plastic bags and cardboard) and disposal of fluorescent lamps. They are fragile and can break easily with subsequent contam- 
ination of mercury. Figure 13c shows improperly stored cathode ray tubes and printers. Both types of equipment include hazardous substances easily released into the environment. In this case, the size of the waste equipment exceeds the dimensions of the input hole of the container.

Regarding proposals to improve the collection rate of small e-waste, the majority of respondents expect to provide seasonal events to collect such equipment (44 percent of participants). Further, the placement of containers in residential areas is expected by 35 percent of respondents. Providing more containers in other supermarkets is welcomed by 21 percent of respondents.

\section{Discussion}

Collection, processing, and recycling require international collaboration, economic incentives, and management approaches that minimize negative impacts on the environment and human health [36]. This also creates an opportunity to access secondary raw materials for recycling [37]. The management of e-waste involves multi-criteria decision-making with recommendations for the improvement of management strategies along the entire supply chain [38]. An efficient reverse supply chain of e-waste requires waste collection companies offering various methods and points for the collection of the end-of-life equipment. Each activity required by the waste collection company incurs the costs of storage, transportation, and employees. Therefore, the total cost for the collection points should not exceed a potential profit from secondary raw materials after recycling e-waste. The optimal location of the collection points was discussed in a study taking into consideration economic, social, and environmental criteria. The findings show transportation cost as the most important for sustainable collection center selection, followed by collection cost and storage cost [39]. The design of the collection network for a large number of collection points and waste collection companies can be achieved by an exact algorithm. [40]. Transportation cost and efficient loading of the collection vehicles contribute to efficient use of the resources and employees [41].

The attitude of individuals towards recycling and the environment is a key factor to participate in the e-waste collections. The differences between developed and developing countries are presented in a review where economic factors are more important for the general population in developing countries and environmental factors are preferred in developed countries [42]. Another study shows the importance of determinants in WEEE recycling behavior [43].

Small e-waste collection rate needs to be improved. For this reason, waste collection companies put the containers in places frequently visited by individuals. The collection of waste of any category requires coordination of various activities. They should focus on education and information brought to the society, indicating benefits of recycling and dangers for the natural environment [44]. Additionally, several options for disposal of the waste should be offered for the residents to achieve a high collection rate [45-47].

The results of this study help to evaluate the placement of containers in various locations as well as the social response for this collection method.

According to the first survey, containers placed in supermarkets and in shopping malls are a good solution, and it is relatively easy to ensure efficient collection by waste collection companies. The managers of supermarkets or shopping malls find a growing interest in the disposal of small e-waste by customers. The cooperation with waste collection companies relies on fixed schedules or on-demand e-waste pick-up. In several cases, some issues and irregularities in collections were observed. Overloading the containers or mixing with other categories of waste was a common issue found in this study. This kind of improper social behavior by mixing various categories of waste together was highlighted by some researches [48-50], including mixing general waste with e-waste [34,51]. The e-waste containers are also not adapted to certain types of waste belonging to the lighting equipment category. Often, fluorescent lamps protruded from the containers, and compact 
fluorescent lamps, were thrown loosely inside. In both cases, the glass may break and release dangerous mercury vapors in publicly frequented places [52].

Other irregularities indicate that the containers are emptied too rarely. The managers should solve these problems by better communication with waste collecting companies. Replacement of the containers that are not suitable for the collection of some categories of e-waste with better-designed and labeled containers is essential. Recent initiatives of local administration managers show the necessity of the placement of containers in residential areas.

Using the collection containers for the disposal of small e-waste items becomes common, but some individuals tend to stockpile small e-waste in households. This behavior makes some disruptions in the reverse supply chain of electronic products $[16,17]$.

One of the most important elements of an effective collection campaign is to make individuals aware of the negative impact of e-waste on the environment [53-55]. Such campaigns can be educational or informative depending on the target audience [56]. Comparing previous studies conducted in Poland [57,58], the level of awareness about the removal of electrical waste into the appropriate container has increased. Educational and information campaigns can be successful, as shown in the results of studies on toys in Spain $[59,60]$ and on mobile phones in Germany [61]. Such campaigns can even start with very early education by parents [62].

The collection containers or bins must be located in places easily noticeable by passersby, and they should be correctly identified [63]. In some cases, shape or color [64], or other features, are decisive for more engagement in recycling or waste disposal [65]. The placement of e-waste containers must be supported by information and education campaigns [66], but it is also required to place containers in frequently visited places and residential areas [53].

The results of this study show the importance of awareness about the dangers of certain substances available in equipment, as is also indicated in other articles [67,68]. However, residents should be aware that each type of small e-waste equipment, even a mobile phone charger or a cable connecting devices, must be properly disposed of. The awareness of the legal disposal of e-waste and environmental hazards is a priority in educational and information campaigns [69-71]. Although it is difficult to estimate real willingness by the general population to participate in recycling activities and proper disposal of e-waste, several studies in the USA [72], India [73] China [71], and Bangladesh [74] investigated this subject and made proposals for improvement.

This article's findings indicate a need to improve the collection rate of small e-waste. In order to do so, it is necessary to combine the activities related to the organization of the collection network, the placing of containers, and ensuring proper cooperation with waste collection companies [75,76]. New developments on collection containers were proposed towards optimization, monitoring, and automation of the collections. Sensor equipped waste collection bins were proposed for planning and route optimization [77,78]. Recent applications show implementation for small e-waste containers in Slovakia for improvement of monitoring and collections planning [79] or to issue discount vouchers to citizens in Italy [80].

Another task is to make sure that small e-waste containers are easily accessible and properly labeled [81-83]. The residents must be informed of the environmental risk and the benefits of recycling in a circular economy. Several initiatives have been undertaken by WEEE organizations, WEEE collection companies, local governments, shopping malls, and supermarkets to address a challenge to increase the collection rate of small e-waste in Poland.

The conclusions of this article show that the container collection is evaluated positively by both-management and residents. There were successful projects conducted that assumed placing small e-waste containers in four cities in Poland. Containers located in residential areas are the most recent initiatives. Containers placed in supermarkets and shopping malls were the subject of previous projects. Several issues with improper storage 
of small e-waste, the risk of environmental contamination by hazardous substances, and failure to inform residents about the location of the containers can be solved by making e-waste containers more noticeable and attractive thanks to better labelling.

Attractive labeling, including advertising slogans, can be easily understood by individuals to promote environmentally conscious disposal of waste [81,84]. Other containers that were installed in supermarkets and shopping malls a few years ago should be labeled in a better way. Small e-waste containers increase the efficiency of waste collection, but some recommendations for the managers and practitioners responsible for e-waste management are necessary.

Recommendations for managers of supermarkets, shopping malls, and a local administration are as follows:

- Better communication with waste collection companies if any irregularities occur;

- Demanding replacement of the older containers with the new ones for better noticeability and safe disposal of e-waste;

- Advertising and information about the possibility of discarding small e-waste on the premises of the shopping area;

- Placement of more containers in easily accessible and frequently visited places in residential areas.

Recommendations for managers of waste collection companies and WEEE organizations are as follows:

- Modelling of the collection network of e-waste. Input data must include population and a potential amount of discarded equipment. The frequency of emptying of the containers should be adapted to the volume of the waste. This allows for route optimization in vehicles collections.

- Using sensor-equipped containers for automatic communication and sending information about the filling level of a container and enabling monitoring and collection optimization;

- Providing information and advertising campaigns for residents and customers of supermarkets;

- Ordering improved construction containers with novel labels and advertising slogans.

\section{Conclusions}

The findings of this research show that the number of places for the disposal of small e-waste increased. Waste collection companies have been placing e-waste collection containers since 2015. Initially, they were located mainly in supermarkets. Recently, they have also been installed in the residential areas. It was an effect of the mutual projects of WEEE organizations and local authorities. The managers of supermarkets and employees responsible for waste collection see a growing interest of residents and supermarket customers' in bringing in end-of-life equipment for disposal. The main issue identified by surveyed managers was mixing of e-waste with other waste categories. They often contained paper or plastic. These findings are also confirmed by the results of the field study from our research. The content of the containers was examined if possible. The main irregularities were: mixing the categories of waste and storing breakable equipment (such as compact or linear fluorescent lamps) improperly. Comparing the results of this survey with the previous studies in Poland, the number of individuals being aware of proper disposal methods of e-waste increased, reaching 87 percent of respondents. The individuals (84 percent) were also aware of the possibility of recycling waste equipment. The information about the location of small e-waste collection containers was mostly accessed by personal observation-63 percent of respondents. The results showed a low number of individuals willing to dispose of small e-waste in the future. This could indicate a lack of information programs or marketing campaigns to encourage the population to dispose of small e-waste. The individuals' evaluation of the containers' noticeability was as of average difficulty. The results of the field study confirm the containers placed in supermarkets or shopping malls lack clear identification and attractive design. The recently 
produced containers located in the residential areas have an attractive design and attractive advertising slogans.

Future work should focus on the identification of categories of e-waste collected in containers. Waste collection companies should support further research to identify the type of equipment, and its amount in a container. These data will allow for waste collection costs analysis and evaluation of the effectiveness for each location of the e-waste containers.

Author Contributions: Conceptualization, P.N., S.K., J.P. and P.S.; investigation, S.K., J.P. and P.S.; methodology, P.N., S.K., J.P. and P.S.; resources, P.N., S.K., J.P. and P.S.; supervision, P.N.; visualization, P.N., S.K., J.P. and P.S.; writing-original draft, P.N., S.K., J.P. and P.S.; writing-review and editing, P.N. All authors have read and agreed to the published version of the manuscript.

Funding: This research was funded by the Rector of the Silesian University of Technology for student research group projects in the framework of the "Initiative of Excellence-Research University"- III Edition 2021.

Institutional Review Board Statement: Not applicable.

Informed Consent Statement: Not applicable.

Data Availability Statement: Data sharing not applicable.

Conflicts of Interest: The authors declare no conflict of interest.

\section{References}

1. European Union Directive 2002/95/EC of The European Parliament and of The Council of 27 January 2003 on the Restriction of the Use of Certain Hazardous Substances in Electrical and Electronic Equipment. Available online: https://eur-lex.europa.eu/ legal-content/EN/TXT/?uri=CELEX:32002L0096 (accessed on 17 September 2021).

2. European Commission Directive 2012/19/EU of the European Parliament and of the Council of 4 July 2012 on Waste Electrical and Electronic Equipment (WEEE)Text with EEA Relevance-LexUriServ.Do. 2012. Available online: https: / / eur-lex.europa.eu/ legal-content/EN/TXT/?uri=CELEX:02012L0019-20180704 (accessed on 17 September 2021).

3. Chung, S.-W.; Murakami-Suzuki, R. A Comparative Study of E-Waste Recycling Systems in Japan, South Korea and Taiwan from the EPR Perspective: Implications for Developing Countries. Available online: https:/ /www.semanticscholar.org/paper/Acomparative-study-of-E-waste-recycling-systems-in-Chung-Rie/0450d8b3f2048688d6763019844c163b9daf0025 (accessed on 19 October 2020).

4. Ongondo, F.; Williams, I.; Cherrett, T. How Are WEEE Doing? A Global Review of the Management of Electrical and Electronic Wastes. Waste Manag. 2010, 31, 714-730. [CrossRef]

5. Mundada, M.N.; Kumar, S.; Shedkar, A.V. E-waste: A New Challenge for Waste Management in India. Int. J. Environ. Stud. 2004, 61, 265-279. [CrossRef]

6. Shinkuma, T.; Managi, S. On the Effectiveness of a License Scheme for E-Waste Recycling: The Challenge of China and India. Environ. Impact Assess. Rev. 2010, 30, 262-267. [CrossRef]

7. Eurostat Waste Electrical and Electronic Equipment (WEEE). Available online: http://epp.eurostat.ec.europa.eu/portal/page/ portal/waste/data/wastestreams/weee (accessed on 20 December 2016).

8. Cucchiella, F.; D’Adamo, I.; Lenny Koh, S.C.; Rosa, P. Recycling of WEEEs: An Economic Assessment of Present and Future e-Waste Streams. Renew. Sustain. Energy Rev. 2015, 51, 263-272. [CrossRef]

9. Isernia, R.; Passaro, R.; Quinto, I.; Thomas, A. The Reverse Supply Chain of the E-Waste Management Processes in a Circular Economy Framework: Evidence from Italy. Sustainability 2019, 11, 2430. [CrossRef]

10. Dahlén, L.; Vukicevic, S.; Meijer, J.-E.; Lagerkvist, A. Comparison of Different Collection Systems for Sorted Household Waste in Sweden. Waste Manag. 2007, 27, 1298-1305. [CrossRef]

11. Nowakowski, P.; Król, A.; Mrówczyńska, B. Supporting Mobile WEEE Collection on Demand: A Method for Multi-Criteria Vehicle Routing, Loading and Cost Optimisation. Waste Manag. 2017, 69, 377-392. [CrossRef] [PubMed]

12. Chi, X.; Streicher-Porte, M.; Wang, M.Y.L.; Reuter, M.A. Informal Electronic Waste Recycling: A Sector Review with Special Focus on China. Waste Manag. 2011, 31, 731-742. [CrossRef]

13. Darby, L.; Obara, L. Household Recycling Behaviour and Attitudes towards the Disposal of Small Electrical and Electronic Equipment. Resour. Conserv. Recycl. 2005, 44, 17-35. [CrossRef]

14. Pierron, X.; Williams, I.; Shaw, P. Extending the Theory of Planned Behaviour Using Behavioural Economics to Reduce and Access Small WEEE Anthropogenic Stocks. Detritus 2021, 14, 54-67. [CrossRef]

15. Dhir, A.; Koshta, N.; Goyal, R.K.; Sakashita, M.; Almotairi, M. Behavioral Reasoning Theory (BRT) Perspectives on E-Waste Recycling and Management. J. Clean. Prod. 2021, 280, 124269. [CrossRef]

16. Wilson, G.T.; Smalley, G.; Suckling, J.R.; Lilley, D.; Lee, J.; Mawle, R. The Hibernating Mobile Phone: Dead Storage as a Barrier to Efficient Electronic Waste Recovery. Waste Manag. 2017, 60, 521-533. [CrossRef] [PubMed] 
17. Nowakowski, P. Investigating the Reasons for Storage of WEEE by Residents-A Potential for Removal from Households. Waste Manag. 2019, 87, 192-203. [CrossRef]

18. Parajuly, K.; Habib, K.; Liu, G. Waste Electrical and Electronic Equipment (WEEE) in Denmark: Flows, Quantities and Management. Resour. Conserv. Recycl. 2017, 123, 85-92. [CrossRef]

19. Ustawa z dnia 11 Września 2015 r. o Zużytym Sprzęcie ELEKTRYCZNYM i elektronicznym (Law Regarding Waste Electrical and Electronic Equipment). Dziennik Ustaw Dz.U. 2015 Poz. 1688. Journal of Laws-Poland. (In Polish). 2015. Available online: https:/ / isap.sejm.gov.pl/isap.nsf/DocDetails.xsp?id=WDU20150001688 (accessed on 17 September 2021).

20. Rozporządzenie Ministra Środowiska z Dnia 21 Lipca 2017 r. w Sprawie Minimalnych Rocznych Poziomów Zbierania Zużytego Sprzętu Elektrycznego i Elektronicznego (Requirements of Minimal Collection Levels of Waste Electrical and Electronic Equipment) Dziennik Ustaw. Dz.U. z 2017 r. poz. 1499. 2017. Journal of Laws-Poland. (In Polish). 2017. Available online: http:/ /isap.sejm.gov.pl/isap.nsf/DocDetails.xsp?id=WDU20170001499 (accessed on 17 September 2021).

21. Główny Inspektorat Ochrony Środowiska. Raport o Funkcjonowaniu Systemu Gospodarki Zużytym Sprzętem Elektrycznym i Elektronicznym w 2017 Roku. (Report about WEEE Management System in Poland in 2017). General Inspectorate of Environment Protection. 2018. Available online: https:/ /www.gios.gov.pl/images/dokumenty/gospodarka_odpadami/zseie/Raport_ZSEiE_ 2017_wersja_ostateczna.pdf (accessed on 18 September 2021). (In Polish)

22. Cui, J.; Roven, H.J. Chapter 20—Electronic Waste. In Waste; Letcher, T.M., Vallero, D.A., Eds.; Academic Press: Boston, MI, USA, 2011; pp. 281-296. ISBN 978-0-12-381475-3.

23. Oguchi, M.; Murakami, S.; Sakanakura, H.; Kida, A.; Kameya, T. A Preliminary Categorization of End-of-Life Electrical and Electronic Equipment as Secondary Metal Resources. Waste Manag. 2011, 31, 2150-2160. [CrossRef]

24. Goodship, V.; Stevels, A. Waste Electrical and Electronic Equipment (WEEE) Handbook; Elsevier Science: Amsterdam, The Netherlands, 2012; ISBN 978-0-85709-633-3.

25. Islam, M.T.; Dias, P.; Huda, N. Young Consumers'e-Waste Awareness, Consumption, Disposal, and Recycling Behavior: A Case Study of University Students in Sydney, Australia. J. Clean. Prod. 2021, 282, 124490. [CrossRef]

26. Alves, R.; Ferreira, K.L.A.; Lima, R.d.S.; Moraes, F.T.F. An Action Research Study for Elaborating and Implementing an Electronic Waste Collection Program in Brazil. Syst. Pract. Action Res. 2021, 34, 91-108. [CrossRef]

27. Shevchenko, T.; Laitala, K.; Danko, Y. Understanding Consumer E-Waste Recycling Behavior: Introducing a New Economic Incentive to Increase the Collection Rates. Sustainability 2019, 11, 2656. [CrossRef]

28. Torretta, V.; Ragazzi, M.; Istrate, I.A.; Rada, E.C. Management of Waste Electrical and Electronic Equipment in Two EU Countries: A Comparison. Waste Manag. 2013, 33, 117-122. [CrossRef]

29. Bahers, J.-B.; Kim, J. Regional Approach of Waste Electrical and Electronic Equipment (WEEE) Management in France. Resour. Conserv. Recycl. 2018, 129, 45-55. [CrossRef]

30. Dagiliūtè, R.; Zabulionis, D.; Sujetovienè, G.; Žaltauskaitè, J. Waste of Electrical and Electronic Equipment: Trends and Awareness among Youths in Lithuania. Waste Manag. Res. J. Int. Solid Wastes Public Clean. Assoc. ISWA 2019, 37, 95-101. [CrossRef]

31. Martinho, G.; Magalhães, D.; Pires, A. Consumer Behavior with Respect to the Consumption and Recycling of Smartphones and Tablets: An Exploratory Study in Portugal. J. Clean. Prod. 2017, 156, 147-158. [CrossRef]

32. Casey, K.; Lichrou, M.; Fitzpatrick, C. Treasured Trash? A Consumer Perspective on Small-waste Electrical and Electronic Equipment (WEEE) Divestment in Ireland. Resour. Conserv. Recycl. 2019, 145, 179-189. [CrossRef]

33. Dhir, A.; Malodia, S.; Awan, U.; Sakashita, M.; Kaur, P. Extended Valence Theory Perspective on Consumers' e-Waste Recycling Intentions in Japan. J. Clean. Prod. 2021, 312, 127443. [CrossRef]

34. Sharma, M.; Joshi, S.; Govindan, K. Issues and Solutions of Electronic Waste Urban Mining for Circular Economy Transition: An Indian Context. J. Environ. Manag. 2021, 290, 112373. [CrossRef]

35. Liu, T.; Cao, J.; Wu, Y.; Weng, Z.; Senthil, R.A.; Yu, L. Exploring Influencing Factors of WEEE Social Recycling Behavior: A Chinese Perspective. J. Clean. Prod. 2021, 312, 127829. [CrossRef]

36. Awasthi, A.K.; Li, J.; Koh, L.; Ogunseitan, O.A. Circular Economy and Electronic Waste. Nat. Electron. 2019, 2, 86-89. [CrossRef]

37. Althaf, S.; Babbitt, C.W.; Chen, R. Forecasting Electronic Waste Flows for Effective Circular Economy Planning. Resour. Conserv. Recycl. 2019, 151, 104362. [CrossRef]

38. Marinello, S.; Gamberini, R. Multi-Criteria Decision Making Approaches Applied to Waste Electrical and Electronic Equipment (WEEE): A Comprehensive Literature Review. Toxics 2021, 9, 13. [CrossRef]

39. Sagnak, M.; Berberoglu, Y.; Memis, İ.; Yazgan, O. Sustainable Collection Center Location Selection in Emerging Economy for Electronic Waste with Fuzzy Best-Worst and Fuzzy TOPSIS. Waste Manag. 2021, 127, 37-47. [CrossRef]

40. Ríos-Mercado, R.Z.; Bard, J.F. An Exact Algorithm for Designing Optimal Districts in the Collection of Waste Electric and Electronic Equipment through an Improved Reformulation. Eur. J. Oper. Res. 2019, 276, 259-271. [CrossRef]

41. Nowakowski, P.; Szwarc, K.; Boryczka, U. Combining an Artificial Intelligence Algorithm and a Novel Vehicle for Sustainable E-Waste Collection. Sci. Total Environ. 2020, 730, 138726. [CrossRef] [PubMed]

42. Shahrasbi, A.; Shokouhyar, S.; Zeidyahyaee, N. Consumers' Behavior towards Electronic Wastes from a Sustainable Development Point of View: An Exploration of Differences between Developed and Developing Countries. Sustain. Prod. Consum. 2021, 28, 1736-1756. [CrossRef]

43. Corsini, F.; Gusmerotti, N.M.; Frey, M. Consumer's Circular Behaviors in Relation to the Purchase, Extension of Life, and End of Life Management of Electrical and Electronic Products: A Review. Sustainability 2020, 12, 443. [CrossRef] 
44. Perkins, D.N.; Drisse, M.-N.B.; Nxele, T.; Sly, P.D. E-Waste: A Global Hazard. Ann. Glob. Health 2014, 80, 286-295. [CrossRef] [PubMed]

45. Robinson, G.M.; Read, A.D. Recycling Behaviour in a London Borough: Results from Large-Scale Household Surveys. Resour. Conserv. Recycl. 2005, 45, 70-83. [CrossRef]

46. Byrne, S.; O'Regan, B. Attitudes and Actions towards Recycling Behaviours in the Limerick, Ireland Region. Resour. Conserv. Recycl. 2014, 87, 89-96. [CrossRef]

47. Williams, I.D.; Kelly, J. Green Waste Collection and the Public's Recycling Behaviour in the Borough of Wyre, England. Resour. Conserv. Recycl. 2003, 38, 139-159. [CrossRef]

48. Geetha, R.; Rajalakshmi, S. Problem Faced by the Public Due to the Improper Waste Disposal and Behaviour of Waste Disposal. Int. J. Soc. Sci. Manag. 2020, 7, 70-77. [CrossRef]

49. Oyekale, A.S. Determinants of Households' Involvement in Waste Separation and Collection for Recycling in South Africa. Environ. Dev. Sustain. 2018, 20, 2343-2371. [CrossRef]

50. Stoeva, K.; Alriksson, S. Influence of Recycling Programmes on Waste Separation Behaviour. Waste Manag. 2017, 68, 732-741. [CrossRef]

51. Huisman, J.; Magalini, F.; Kuehr, R.; Maurer, C.; Delgado, C.; Artim, E.; Stevels, A.L.N. 2008 Review of Directive 2002/96 on Waste Electrical \& Electronic Equipment (WEEE) Final Report; United Nations University: Bonn, Germany, 2007.

52. Johnson, N.C.; Manchester, S.; Sarin, L.; Gao, Y.; Kulaots, I.; Hurt, R.H. Mercury Vapor Release from Broken Compact Fluorescent Lamps and In Situ Capture by New Nanomaterial Sorbents. Environ. Sci. Technol. 2008, 42, 5772-5778. [CrossRef]

53. Suttibak, S.; Nitivattananon, V. Assessment of Factors Influencing the Performance of Solid Waste Recycling Programs. Resour. Conserv. Recycl. 2008, 53, 45-56. [CrossRef]

54. Tonglet, M.; Phillips, P.S.; Bates, M.P. Determining the Drivers for Householder Pro-Environmental Behaviour: Waste Minimisation Compared to Recycling. Resour. Conserv. Recycl. 2004, 42, 27-48. [CrossRef]

55. Chang, H.; Zhang, L.; Xie, G.-X. Message Framing in Green Advertising: The Effect of Construal Level and Consumer Environmental Concern. Int. J. Advert. 2015, 34, 158-176. [CrossRef]

56. Welfens, M.J.; Nordmann, J.; Seibt, A. Drivers and Barriers to Return and Recycling of Mobile Phones. Case Studies of Communication and Collection Campaigns. J. Clean. Prod. 2016, 132, 108-121. [CrossRef]

57. Nowakowski, P. A Proposal to Improve E-Waste Collection Efficiency in Urban Mining: Container Loading and Vehicle Routing Problems-A Case Study of Poland. Waste Manag. 2017, 60, 494-504. [CrossRef]

58. Nowakowski, P. The Influence of Residents' Behaviour on Waste Electrical and Electronic Equipment Collection Effectiveness. Waste Manag. Res. 2016, 34, 1126-1135. [CrossRef]

59. Pérez-Belis, V.; Bovea, M.D.; Simó, A. Consumer Behaviour and Environmental Education in the Field of Waste Electrical and Electronic Toys: A Spanish Case Study. Waste Manag. 2015, 36, 277-288. [CrossRef]

60. Solé, M.; Watson, J.; Puig, R.; Fullana-i-Palmer, P. Proposal of a New Model to Improve the Collection of Small WEEE: A Pilot Project for the Recovery and Recycling of Toys. Waste Manag. Res. 2012, 30, 1208-1212. [CrossRef] [PubMed]

61. Baxter, J.; Gram-Hanssen, I. Environmental Message Framing: Enhancing Consumer Recycling of Mobile Phones. Resour. Conserv. Recycl. 2016, 109, 96-101. [CrossRef]

62. Herdiansyah, H.; Brotosusilo, A.; Negoro, H.A.; Sari, R.; Zakianis, Z. Parental Education and Good Child Habits to Encourage Sustainable Littering Behavior. Sustainability 2021, 13, 8645. [CrossRef]

63. Wu, D.W.-L.; Lenkic, P.J.; DiGiacomo, A.; Cech, P.; Zhao, J.; Kingstone, A. How Does the Design of Waste Disposal Signage Influence Waste Disposal Behavior? J. Environ. Psychol. 2018, 58, 77-85. [CrossRef]

64. Leeabai, N.; Areeprasert, C.; Khaobang, C.; Viriyapanitchakij, N.; Bussa, B.; Dilinazi, D.; Takahashi, F. The Effects of Color Preference and Noticeability of Trash Bins on Waste Collection Performance and Waste-Sorting Behaviors. Waste Manag. 2021, 121, 153-163. [CrossRef]

65. Keramitsoglou, K.M.; Tsagarakis, K.P. Public Participation in Designing the Recycling Bins to Encourage Recycling. Sustainability 2018, 10, 1240. [CrossRef]

66. Shi, J.; Wang, R.; Chen, W.; Xing, L.; Jin, M. Bi-Objective Design of Household E-Waste Collection with Public Advertising and Competition from Informal Sectors. Waste Manag. 2020, 102, 65-75. [CrossRef]

67. Milovantseva, N.; Saphores, J.-D. Time Bomb or Hidden Treasure? Characteristics of Junk TVs and of the US Households Who Store Them. Waste Manag. 2013, 33, 519-529. [CrossRef]

68. Saphores, J.-D.M.; Ogunseitan, O.A.; Shapiro, A.A. Willingness to Engage in a Pro-Environmental Behavior: An Analysis of e-Waste Recycling Based on a National Survey of U.S. Households. Resour. Conserv. Recycl. 2012, 60, 49-63. [CrossRef]

69. Borthakur, A.; Govind, M. Public Understandings of E-Waste and Its Disposal in Urban India: From a Review towards a Conceptual Framework. J. Clean. Prod. 2018, 172, 1053-1066. [CrossRef]

70. Kumar, A. Exploring Young Adults' e-Waste Recycling Behaviour Using an Extended Theory of Planned Behaviour Model: A Cross-Cultural Study. Resour. Conserv. Recycl. 2019, 141, 378-389. [CrossRef]

71. Zhang, B.; Du, Z.; Wang, B.; Wang, Z. Motivation and Challenges for E-Commerce in e-Waste Recycling under "Big Data" Context: A Perspective from Household Willingness in China. Technol. Forecast. Soc. Chang. 2019, 144, 436-444. [CrossRef]

72. Saphores, J.-D.M.; Nixon, H.; Ogunseitan, O.A.; Shapiro, A.A. Household Willingness to Recycle Electronic Waste: An Application to California. Environ. Behav. 2006, 38, 183-208. [CrossRef]

73. Dwivedy, M.; Mittal, R.K. Willingness of Residents to Participate in E-Waste Recycling in India. Environ. Dev. 2013, 6, 48-68. [CrossRef] 
74. Islam, M.T.; Abdullah, A.B.; Shahir, S.A.; Kalam, M.A.; Masjuki, H.H.; Shumon, R.; Rashid, M.H. A Public Survey on Knowledge, Awareness, Attitude and Willingness to Pay for WEEE Management: Case Study in Bangladesh. J. Clean. Prod. 2016, 137, 728-740. [CrossRef]

75. Hemmelmayr, V.C.; Doerner, K.F.; Hartl, R.F.; Vigo, D. Models and Algorithms for the Integrated Planning of Bin Allocation and Vehicle Routing in Solid Waste Management. Transp. Sci. 2014, 48, 103-120. [CrossRef]

76. Singh, S.; Dasgupta, M.S.; Routroy, S. Evaluation of Sustainable E-Waste Collection Method for Urban and Rural Region of India. Waste Manag. Res. 2021. [CrossRef]

77. Abuga, D.; Raghava, N.S. Real-Time Smart Garbage Bin Mechanism for Solid Waste Management in Smart Cities. Sustain. Cities Soc. 2021, 75, 103347. [CrossRef]

78. Enevo Better Waste Management-Enevo-Enevo. 2021. Available online: https:/ / enevo.com/ (accessed on 1 November 2021).

79. Brunn, M.; Asekol Reveals Impact of Smart Monitoring on Collection of Electronic Waste. Recycling Magazine-Online Version 2021. Available online: https:/ / www.recycling-magazine.com/2021/10/14/asekol-reveals-impact-of-smart-monitoring-oncollection-of-electronic-waste/ (accessed on 18 October 2021).

80. Smart Green Post. Smart Bin, the Electronic Waste Container That Makes Discounts. 2020. Available online: https:/ / www.smartgreenpost. com/2020/11/05/smart-bin-the-electronic-waste-container-that-makes-discounts/ (accessed on 1 November 2021).

81. Jiang, Q.; Izumi, T.; Yoshida, H.; Dilixiati, D.; Leeabai, N.; Suzuki, S.; Takahashi, F. The Effect of Recycling Bin Design on PET Bottle Collection Performance. Waste Manag. 2019, 95, 32-42. [CrossRef] [PubMed]

82. Mishima, K.; Nishimura, H. Requirement Analysis to Promote Small-Sized E-Waste Collection from Consumers. Waste Manag. Res. 2016, 34, 122-128. [CrossRef]

83. Vlastimir, N.; Radovan, S.; Lukas, K.; Veronika, S.; Josef, J. Municipal Solid Waste Container Location Based on Walking Distance and Distribution of Population. Chem. Eng. Trans. 2019, 76, 553-558. [CrossRef]

84. Balderas, B.J.; Cabilzo, R.D.; Zuñiga, M.Y.; Sedilla, K. Improving Garbage Receptacles: Designing an Affective Garbage Receptacle That Influences Human Behavior Towards Littering. In Advances in Affective and Pleasurable Design; Fukuda, S., Ed.; Springer International Publishing: Cham, Switzerland, 2020; pp. 391-401. 